\title{
Feminist Judgments Projects at the Intersection
}

\author{
Vanessa E. Munro ${ }^{1}$
}

Published online: 18 April 2020

(C) The Author(s) 2020

Shared Reflections on a Dialogue between Members of the African (Martha Gayoye [University of Warwick, UK], Mateena Hunter [Independent Legal Research Consultant, South Africa], Ambreena Manji [University of Cardiff, UK], Miriam Matinda [Tumaini University, Tanzania], and Sharifah Sekalala [University of Warwick, UK]), Indian (Rachna Chaudhary [Ambedkar University Delhi, India], Laura Lammasniemi [University of Warwick, UK], Shreya Munoth [Advocate and Partner, Chakravorty, Samson \& Munoth, India], Devyani Prabhat [University of Bristol, UK], and Jhuma Sen [Jindal Global Law School]) and Scottish Feminist Judgments Project (Gillian Black [University of Edinburgh, UK], Sharon Cowan [University of Edinburgh, UK], Chloë Kennedy [University of Edinburgh, UK], and Vanessa E. Munro [University of Warwick, UK])

\section{Introduction}

On 25th and 26th July 2019, ten members of the African, Indian and Scottish Feminist Judgments Projects (FJPs), comprised of legal academics and legal practitioners, met at Edinburgh Law School in Scotland. We were also joined at various points in our discussions by a number of invited guests from the Scottish academic, legal and feminist activist communities. In the context of ongoing global conversations across diverse FJPs, the purpose of our meeting was to explore the connections between these three then in-progress FJPs, to reflect on the experience of being involved in an FJP

Munro coordinated production of this piece, and as such is listed as corresponding author, but these reflections were co-authored collaboratively by all those named in the abstract. Special thanks are due to Martha Gayoye for her additional research assistance.

Shared Reflections on a Dialogue between Members of the African (Martha Gayoye [University of Warwick, UK], Mateena Hunter [Independent Legal Research Consultant, South Africa], Ambreena Manji [University of Cardiff, UK], Miriam Matinda [Tumaini University, Tanzania], and Sharifah Sekalala [University of Warwick, UK]), Indian (Rachna Chaudhary [Ambedkar University Delhi, India], Laura Lammasniemi [University of Warwick, UK], Shreya Munoth [Advocate and Partner, Chakravorty, Samson \& Munoth, India], Devyani Prabhat [University of Bristol, UK], and Jhuma Sen [Jindal Global Law School]) and Scottish Feminist Judgments Project (Gillian Black [University of Edinburgh, UK], Sharon Cowan [University of Edinburgh, UK], Chloë Kennedy [University of Edinburgh, UK], and Vanessa E. Munro [University of Warwick, UK])

Vanessa E. Munro

V.Munro@warwick.ac.uk

1 Warwick Law School, Coventry, UK 
within our respective jurisdictions, and to discuss both the pitfalls and possibilities for creating legacies in teaching, scholarship and practice (see also Cowan et al. 2018).

Each of these three FJPs was at a different stage when we met. The Scottish Feminist Judgments Project (SFJP) was nearing its completion, having commenced some two years previously. This volume of rewritten judgments has now been published (Cowan et al. 2019). The Indian Feminist Judgments Project (IFJP) had organised two workshops, compiled a first volume - to be published as a journal special issueand had made plans for additional outputs to follow. A curriculum for the teaching of a bespoke module based around the IFJP in universities had also been developed. Meanwhile, the African Feminist Judgments Project (AFJP) was still in its early conception phase. AFJP participants had met twice in the latter half of 2018 to discuss the scope of the project and to present some of their proposed feminist rewrites. Ultimately, what is envisaged is a pan-African feminist judgments project, but the AFJP has always sought to be modest about its capacity to represent the complexity and plurality of the continent; and as a starting point, for several reasons including language logistics and patterns of expressed interest, the current round of rewrites is focused mostly on eastern and southern Africa, and some African Commission cases.

In this paper, we give an account of some of the conversations that took place during that two-day workshop, which we think may be of interest and value to others in the feminist community, particularly but not solely if they are engaged in FJPs. Specifically, we discuss questions of how best to celebrate and use, but also constructively build upon and perhaps even push beyond, the legacies of earlier FJPs; the difficulties of re-affirming common law traditions imposed from the outside in the process of writing feminist judgments, and the particular challenges that this poses in a post-colonial context; the use within FJPs of 'gender' as a category through which to interrogate and redress historical inequalities; the ability of FJPs in general, and these projects in particular, to cast new light on long-standing methods within feminist legal theory; the concept of feminist lawyering; and the potential for critical engagement with the legal profession. In the final section, we also briefly explore some tentative ideas for future collaboration to promote further dialogue between FJPs across the world.

\section{Building on, and beyond, our foundations}

Each feminist judgment project has, of course, been a reflection of the limits of critical possibility at the time and context in which it was written. Building on the first FJP — the Women's Court of Canada (Majury 2006) — which itself was inspired by the original US critical race judgments project that rewrote Brown v Board of Education (Balkin 2002), the trajectory of FJPs that have come since has reflected a growing capacity for boldness, secured as a result of the successes of their predecessors. We see this desire to 'push beyond' manifested, for example, in the inclusion of a 'future 
dated' feminist judgment in the Australian FJP (Douglas et al. 2014) and a dedicated section on Māori judgments in the New Zealand project (McDonald et al. 2017).

In their different ways, and within their very different contexts, each of the projects represented at the Edinburgh workshop has similarly taken a conscious decision to build upon, but also beyond, the foundations of previous FJPs. The SFJP, for example-inspired in part by the inclusion in the Northern/Irish FJP of poetry (Enright et al. 2017) — took steps from the outset to develop a creative strand that would complement, and challenge, the judgment-writing component. Thus, eight artists produced pieces in response to particular judgments or the enterprise of feminist judging as a whole, using poetry, creative writing, photography, textile sculpture, theatre, music and illustration. Exhibitions of that artwork have been hosted across Scotland, including at the Scottish Parliament and the Edinburgh Fringe Festival, as well as in a number of public galleries and via a digital exhibition. ${ }^{1}$

Why did the SFJP do this? The aims were both to spark a broader, public conversation about the operation of law and judicial power, and to bring to the fore the emotive, visceral and human dimensions of legal judgments. Art "is a powerful device that can generate resistance, reflection and understanding" (Hewitt 2017). Specifically with respect to the law, art helps us reconnect with the messiness of life (Ben-Dor 2011), taking the arid, partial text of a case report or statute and opening it up to expose the vulnerable human lives at its core. Those who may only have experienced the law second hand, and who would not be likely to buy an academic feminist judgments book, might reach a better understanding of the impact of law 'in the real world' if it is presented to them in more accessible — and provocative — ways (Cowan et al. 2020a).

Feedback from those members of the public who attended exhibitions and engaged with the SFJP artwork certainly indicated that it had this effect. But it also became clear, as we discussed at the workshop, that the art had been profoundly affecting for many of those already 'inside the law' too—-students, lawyers, and indeed judges. For these people, it often prompted a more direct confrontation with the power and reach of law, deepening their reflections on the ethical nature of the choices they make when they encounter, use and apply the law (Cowan et al. 2020a). Art, of course, also introduces a different framework and language with which to critique the law-new tools to 'dismantle the master's house' (Lorde 1984) — and, as is reflected on further below, that can be particularly useful for FJPs, given that their perceived 'credibility' is at least partially purchased at the cost of re-deploying conventional legal methods.

For the IFJP and AFJP, there were other ways they had, or envisaged being able to, bring about this dual gesture of building upon but also travelling beyond preceding FJPs. Both projects are larger in geographical scale than the SFJP and involve more contributors than previous projects (excepting perhaps the US project with its multiple planned volumes). Further, while previous FJPs have included judges and commentators from non-academic and/or non-legal backgrounds, the IFJP and AFJP have both been conceived from the outset to include a higher proportion of contributors from diverse backgrounds. Some of these have been involved in the original cases, re-written for the FJP, as activists or litigants, and so bring intimate knowledge of the cases and their complexities. Indeed, contributors to the AFJP emphasised that the

1 https://www.sfjp.law.ed.ac.uk/virtual-exhibition/. 
reality of litigation in many African jurisdictions is such that the boundary separating legal practice from legal academia is particularly porous: courts often interact with and seek to rely on a broad range of expertise, for example, though the mechanism of the amicus curae. But this was also experienced in both projects as a 'double-edged' phenomenon, since it raised difficult questions about the importance of 'recognisability'-that is, of the extent to which judgments must be constructed in a form that is 'credible' and 'usable' if they are to be used as the inspiration for future litigation.

As we discuss below, while the 'recognisability' dilemma has arisen in all FJPs, the associated challenges, costs and benefits can vary significantly across different jurisdictional contexts. And in the AFJP, moreover, adherence to legal form is further complicated by the existence of two or more legal systems in many African countries, where laws of British, French, Portuguese or Roman-Dutch origin can be found alongside uncodified customary law, overlaid with regional and international doctrine.

\section{Common law legacies and postcolonial futures}

As with preceding FJPs, then, those involved in the Scottish, Indian and African FJPs had all struggled in different ways with how to 'tread the line' between mounting the sorts of challenges that feminists have long made to law's claims to objectivity, coherence and neutrality whilst simultaneously aiming to be 'taken seriously' by practitioners who operate in the spaces where those false promises are typically espoused and perpetuated. In line with this, the question of what is gained and lost in the process of adhering to common law methods, which in themselves are often sites of oppression, was much discussed in our workshop. We explored together what freedom there was in a feminist judgment to raise new arguments and cite different authorities, or experiment with 'unconventional' communication mediums; and of what alternative toolkits (including the artistic) could be used to effect some disruption.

This, of course, is by no means a new dilemma, and nor is it one restricted solely to contemporary FJPs. Over 3 decades ago, Whitman $(1988,1389)$ asked: "must you choose between a language of neutrality, which provides credibility but disables you from saying those things you most need to say, and a feminist language, which allows you to say those things at the cost of being believed?". We wrangled with this question in our workshop, and though — unsurprisingly perhaps — we did not manage to resolve it, we reflected on the power that comes from candidly acknowledging the dilemma itself. For the SFJP that meant giving judgment writers space to produce reflective statements, published in the book after each judgment and commentary. In these statements, judges share honest reflections about the trade-offs they made, the calculus of costs and benefits that lay behind these, and their experience of such compromises. The AFJP plans to take a similar approach, supplementing fairly traditional judgment rewrites with reflective and critical commentaries that allow the expression of wider concerns about the limits of law, legal strategies and legal language. Meanwhile, heeding warnings the project had received from mentors, including serving and retired judges, not to become 'too creative' around the format lest the project lose its credibility, the IFJP will integrate judgments and commentaries 
into a single article in its forthcoming special issue. Project coordinators noted, though, this made it hard 'to give adequate space to judgment and commentary writers to bring in criticality and reflexivity to the rewriting within the conventional format'.

Of course, in the context of the Global South, FJPs are laced with further layers of complexity due to their relationship with colonial law. Mohanty, amongst many others, has underscored the need for feminists to take into account both the distinctive legacies of colonial pasts and aspirations for postcolonial futures, and to lay bare the impacts that they have on the daily realities of women's lives (Mohanty 1988). But how to reconcile this with the use of - eminently colonial-inherited forms of legal reasoning within a modern feminist project? Representatives from the IFJP remarked on the particular difficulties that arise in rewriting judgments that were decided in colonial times, by a colonial judge, following colonial legal transplants; and posed the question of how, if it all, it is possible for a feminist judge to work ethically and critically within a colonial legal system. Relatedly, representatives from the AFJP talked of wrangling with core questions over 'what it means to do feminist legal activism on the continent' and 'how you challenge patriarchy without falling into the trap of ethnocentric law'.

Such concerns were expressed forcefully by Joyce Banda, the first woman President of Malawi, who recently reflected that: "so-called Western feminism can't work here... We are not going to achieve gender equality by using models that we borrow from elsewhere." Instead, she has credited the progress that has been made to date in Africa to the legacy of its precolonial women leaders, whose powers were weakened by patriarchal colonial influences (Abouzeid 2019). AFJP representatives observed that - in both academia and the courts-African feminist jurisprudence is stll emergent, and female lawyers are only part of a rich mosaic of gender activists, and so these concerns were at the forefront of the process and parameters of rewriting judgments.

Though clearly the experiences, and consequences, of its colonial legacies are very different, the Northern/Irish FJP also grappled with the relationship between national and legal identity. And so too in the SFJP there was a need to reflect on how feminists have negotiated a national legal and political landscape that was shaped by the union with England in 1707 and the resurrection of the Scottish Parliament in 1999. One of the ways the SFJP did this was by holding a focus group with key members of the Scottish feminist activist community, to reflect with them on how the relatively compact political geography of the country, particularly post-devolution, had changed their approach to law reform campaigns; and to consider the ongoing importance of the courtroom as a site for pursuing progressive legal outcomes. In a similar spirit, the IFJP has sought to foster a stronger connection between academics and activists, and to reclaim a feminist history in which campaigning created conditions for legal victories. One of the ways they have done so involved hosting an exhibition during an event that charted various phases of autonomous women's movements across India.

As noted above, the contexts and compositions of both the IFJP and AFJP make them perhaps better positioned to centre this academic/activist dialogue than previous FJPs. Both involve a number of lawyers as contributors, who have themselves 
been at the cutting edge of strategic litigation, exposing courts to a plurality of perspectives on critical matters such as the state's obligations in respect of the realisation of social and economic rights. Crucially, this has also led to a flourishing of South-South legal conversations with expert witnesses from South Africa serving in Kenya, for example, or Indian experts taking part in South African constitutional cases: a development that we believe affirms the salience and potential of collaboration across sister FJPs.

\section{History, gender and the spaces between}

Another area of lively discussion at the workshop related to FJPs' uses of history and the ways these uses are themselves affected by time and place. The persistence of common law logics attests to the fact that history and tradition are often used to thwart progressive initiatives. The purported fact that 'things have always been this way' imbues the status quo with normative force. In a colonial setting, of course, that status quo is itself the consequence of a series of imposed ruptures, which the colonised might — both historically and currently_reject or resist. This means that adherence to tradition can easily be deployed as a strategy to support conservatism but, equally, that relying on history also has emancipatory potential. Oppressive norms and practices can be destabilised through genealogical critique that reveals their contingency, and indigenous pasts can be mined for alternative futures. Presenting reform in this way may also-sometimes_-increase its public and political palatability.

Moreover, older judgments whose problematic features may seem obvious now can be acknowledged as having been more complex when placed in their temporal context. And, in turn, recognising this heightens our appreciation that what seems reasonable now will no doubt come to be seen as dated and irrational in due course. A deep understanding of older cases can therefore reveal that they involved problems that were as divisive then as those gendered dilemmas and injustices that are familiar to us are now. In a similar way, paying attention to history can show how progressive ambitions (e.g. to improve women's position) of the past generated as varied and as conflicting a set of commitments as do the progressive ambitions of our own time.

Part of the value of taking history seriously in this way, then, is that it helps us get better at identifying patterns and practices of oppression, teasing apart the plurality of 'progressive' perspectives and identifying which of these is likely to have (perhaps unintended) negative consequences for women and/or other disenfranchised groups. It is also a way of avoiding the kind of cultural arrogance that leads us to assume that our contemporary challenges are unique or our strategies for dealing with them are new. Being alive to cultural arrogance might also make us question, in earnest, whether the growth of FJPs, with the specific model and trajectory they have adopted, might-worryingly — be conceived as a colonialist enterprise in its own right.

Going further, adopting a historically-informed perspective allows us to question not only the 'taken for grantedness' of historical frameworks of precedent but also historical constructions of gender across and within distinctive cultures. In retracing the historical interventions in the relationship between law and gender, FJPs 
can both interrupt sequences of confirmation bias and illuminate the complexity and diversity of female experiences and feminist aspirations. This matters, discussants emphasised, because at the heart of FJPs is a commitment to avoid replacing the privileged male perspective with one privileged feminist alternative, which reallocates but does not dismantle the dynamics of power implicated across intersectional vectors of-amongst myriad others-race, ethnicity, caste, age, class and sexuality, as well as gender.

\section{Re-focusing feminist legal theory}

One of the many strengths of FJPs is their ability to work simultaneously at a practical and theoretical level. Though, as discussed above, feminist judges can be required at times to tread a perilous path in 'using the masters' tools' (Lorde 1984), their resultant re-imagined judgments also provide a powerful, and profoundly concrete, illustration of the difference that gender difference can, and does, make to legal decision-making. In this respect, they are inevitably in close conversation with feminist legal theory.

But how do we hold the multiple strands of this practical and theoretical complexity together across different socio-political and cultural contexts? Does it mean the same thing in Scotland, India and Africa to "ask the woman question" (Bartlett $1990,829)$ ? Does it even make sense to frame the enterprise in this way in environments where conceptions of the self, and the relationship between individual and community, may be quite different from those embedded in western, liberal frameworks? Where do we position issues of legal pluralism and customary law-and the complicated psychological and historical mesh in which these are embroiled? How, for example, would an 'African' woman question (and is there even such a thing as a pan-African woman question?) address questions of polygamy and its effect on the inheritance and division of property upon death or the dissolution of marriage? It is well-known that those able to challenge oppression are seldom the dispossessed, and this has implications too for the connections between feminist activism and progressive judicial decision-making. As discussants from the IFJP noted, educated and professionally secure women have, for example, challenged the lack of equal rights to custody and guardianship over children; and while such challenges often generated improved outcomes, they generally emerged from long drawn-out legal battles that involved little grassroots mobilisation. In this sense, litigation as a strategy of law reform can serve to distance and alienate from, as well as connect to, feminist political activism.

Naturally, optimal solutions are not always easy to find-or choose-but FJPs have the potential to make vital new contributions in addressing these challenges. Conaghan (2000) notes there has been a shift towards 'micro' scales of analysis and 'strategic' political objectives in contemporary feminist legal theory (see also Munro 2007). This has redressed some of the monolithic and grandiose claims to truth associated with previous feminist approaches. However, this shift is only a small part of what is needed to engage in collective action and reflect on what feminist strategies are required within this contemporary terrain. Programmes of analysis built around 
the legacies of 1980s North American and western European 'second wave' feminism—such as 'asking the woman question', critiquing 'public/private' dichotomies, and interrogating the boundaries of legal definition - are undoubtedly still pertinent. But we must also avoid reproducing and universalising what Aziz (1992) has called "white feminism", or adding simply a veneer of inclusion of the post-national global "other" (Ang 2003). Rather we must ask what variety of other techniques-of empathy, active listening, and intersectional analysis, for example-are now required, and how do we turn them from abstract theory into tools that assist concrete feminist action (Atrey 2018)? In combining theoretical and political ambitions with strategies for active intervention and litigation, FJPs offer an opportunity to push towards developing new, contextually grounded and nuanced techniques of feminist legal intervention.

This potential for feminist legal disruption also underscores the importance of rewriting judgments not only from the uppermost courts-where there is greater authority for judges to depart from precedent and perhaps more scope to engineer dramatic shifts in outcome-but also from lower courts, where the majority of practitioners and judges operate and where much of the 'mundane but vital' work of relevance-testing, boundary-definition and authority-setting takes place. Turning feminist attention to these lower court decisions has the potential to shift terrain, albeit perhaps in more subtle ways-by repositioning factual narratives or adjusting the framing and tone of the judgment. Of course, translating such shifts into 'real world' practice also requires equipping counsel to bring forward feminist arguments, so that these approaches can be put before judges in order for them to make truly progressive and bold decisions.

\section{Feminist lawyering and legal education}

The need to attend to strategies of feminist argument led us naturally in the workshop to a conversation about feminist lawyering, and the capacity of FJPs to feed its development. Previous research has maintained that female lawyers are more likely than their male counterparts to practise an 'ethic of care' in legal reasoning which entails trying to resolve conflicts, where possible, through preserving connection and relationship (Jack and Jack 1989; Noddings 1984). To what extent should feminist lawyers lay claim to this unique perspective (as distinct from a more 'rights' oriented and competitive, adversarial framework), and to what extent does it disadvantage them? What role can the enterprise of FJPs play in 'feminising' the legal and adversarial space? And what insight can it offer within that space regarding how to reconcile potential tensions between what may be the 'best' feminist outcome in any given case with the 'best' feminist intervention for collective or strategic purposes?

Cahn $(1992,1040)$ has argued that "feminist theory teaches us how to use these different lawyering styles to challenge existing practices, and can change the way we practice, how we think about ourselves as lawyers, and how we think about our clients." The scale of such change is substantial, of course, but not insurmountable. Indeed, Abrams (1991, 375) notes: "to assume a chronic tension between 'feminist method' and 'legal method' that ultimately condemns the former to failure seems 
both pessimistic and oddly static...feminist lawyers may be temporarily delegitimized by their departures from methodological conventions [but] their participation in the legal system also contributes to the ongoing reformulation of those conventions." In our discussions, we reflected on how to use FJPs as a mechanism to deepen engagement with feminist lawyering: and we were fortunate to have insights from the Scottish Law Commission, Scottish Government, Crown Office and Procurator Service, as well as the Faculty of Advocates, to help us think about how best to begin doing this.

Allied to this, we also spoke about the importance of inspiring future generations of practitioners to engage with FJPs through the law school curriculum. Building on a Canadian initiative that took their Women's Court judgments 'on tour', the SFJP spoke of its plans to deliver workshops on feminist judging to students across Scottish law schools. In September 2019, the SFJP academic coordinators did so-by bicycle-to reference the status of the bicycle as a symbol of women's emancipation and to raise funds for Rape Crisis Scotland, Scottish Women's Aid and the Scottish Trans Alliance. ${ }^{2}$ The workshops involved a half-day session, based around selected cases, which aimed to develop students' feminist legal analysis and judgment writing skills. Students were also given the opportunity to engage with the SFJP artwork and to respond creatively, including through writing their own 'found' poems (Cowan et al. 2020b). Of course, the scale of Scotland enabled this tour in a way that would be less feasible in India or Africa (particularly by bicycle!). However, it is also a key objective of the IFJP and AFJP to engage with 'critical friends' from the legal profession (including advocates and judges), as well as academics, students and civil society (see also Harrington and Manji 2019). The aim is to provide contextually-grounded critical education, tools and inspiration to current and future litigators, and to help in 'messaging', promoting and ensuring the reach of feminist judgments once published.

Across all three projects, there is also a commitment to see how feminist judging might be more effectively embedded within the mainstream curriculum of law schools. In the workshop, we reflected on the experiences of peers who had used feminist judgments in their classrooms - whether as part of core or optional law modules (see also Crawford et al. 2020). We spoke in particular about the dilemma of where best to position FJPs pedagogically, and the lessons that they can provide, within the legal curriculum-does introducing them in core modules underscore the marginality of their critical perspective against an otherwise unchallenged orthodoxy: a kind of superfluous flurry at the end of the module that students know will not make it into the exam? While reserving engagement with them to optional modules - in gender, for examplemight enable more sustained and serious reflection, does it not also only underscore further the idea that feminist approaches are not necessary for students' core legal skills and knowledge? We were fortunate to be able to consult the curriculum of a bespoke feminist judgments module, arising out of the IFJP, in order to consider its transferability to different jurisdictional and educational contexts. But that discussion left us in no doubt of the cultural and institutional challenges involved in doing so.

\footnotetext{
$\overline{2}$ https://www.sjp.law.ed.ac.uk/2019/10/03/sfp-university-tour-2019/.
} 


\section{Challenging futures: Where next?}

The aim of our FJP meeting was to explore commonalities and challenges across our projects rather than to make concrete plans or provide determinative responses. But the conversations were productive and constructive, and highlighted the potential for greater collaboration across global FJPs. The international 'contagion' of FJPsand other sorts of critical projects such as the Ethical Judgments Project (rewriting medical law decisions, Smith et al. 2017) and the Children's Judgments Project (Stalford et al. 2017)—ought to be celebrated loudly as well as reflected on critically. As part of this, we wanted to explore how we might realise their potential to be more than the sum of their individual parts. Amongst the ideas we discussed were cross-jurisdictional feminist moots, which would give opportunities for law students from different common law systems to work together to present feminist arguments. We also spoke about projects that might exist across, rather than between, jurisdictions, generating feminist judgments on the same subject area-for example, asylum law-from distinctive systemic and jurisdictional starting points. This would, we thought, offer an opportunity to twist the kaleidoscopic lens on critical decision-making in new and vital ways, both to create fresh insights upon substantive issues and to facilitate greater feminist solidarity across borders by transcending our national boundaries.

Finally, we reflected on the absence to date of FJPs from Civilian jurisdictions. This has particular implications, of course, for the AFJP, since it is a continent that includes mixed systems, but it was noted that there is also something of an ongoing debate in Scotland too as to its status as a mixed jurisdiction (Cowan et al. 2019). There are, no doubt, distinctive challenges associated with Civil law FJPs, stemming amongst other things from the prevalence of legal codes in Civilian jurisdictions and differing conceptions of the judicial role and trial. Still, projects that engage with how the tools and techniques of FJPs may play out in such contexts, and how they relate to their common law counterparts, will open up new issues for future feminist analysis.

Open Access This article is licensed under a Creative Commons Attribution 4.0 International License, which permits use, sharing, adaptation, distribution and reproduction in any medium or format, as long as you give appropriate credit to the original author(s) and the source, provide a link to the Creative Commons licence, and indicate if changes were made. The images or other third party material in this article are included in the article's Creative Commons licence, unless indicated otherwise in a credit line to the material. If material is not included in the article's Creative Commons licence and your intended use is not permitted by statutory regulation or exceeds the permitted use, you will need to obtain permission directly from the copyright holder. To view a copy of this licence, visit http://creativecommons.org/licenses/by/4.0/.

\section{References}

Abouzeid, Rania. 2019. Around the World, Women are Taking Charge of Their Future. National Geographic, October 2019. https:/www.nationalgeographic.com/culture/2019/10/women-are-takin g-charge-of-their-future-around-the-world-feature/.

Ang, Ien. 2003. 'I'm a Feminist but ..." 'Other' Women and Postnational Feminism. In Feminist Postcolonial Theory: A Reader, ed. Reina Lewis and Sara Mills, 190-206. Edinburgh: Edinburgh University Press. 
Atrey, Shreya. 2018. Comparison in Intersectional Discrimination. Legal Studies 38(3): 379-395.

Aziz, Razia. 1992. Feminism and the Challenge of Racism: Deviance or Difference? In Knowing Women: Feminism and Knowledge, ed. Helen Crowley and Susan Himmelweit, 291-305. Cambridge: Polity Press.

Abrams, Kathryn. 1991. Feminist Lawyering and Legal Method. Law and Social Inquiry 16(2): 373-404. Balkin, Jack (ed.). 2002. What Brown v. Board of Education Should Have Said: The Nation's Top Legal Experts Rewrite America's Landmark Civil Rights Decision. New York: New York University Press.

Bartlett, Katharine. 1990. Feminist Legal Methods. Harvard Law Review 103: 829-888.

Ben-Dor, Oren (ed.). 2011. Law and Art: Justice, Ethics and Aesthetics. London: Routledge-Cavendish.

Cahn, Naomi. 1992. Styles of Lawyering. Hastings Law Journal 43: 1039-1070.

Conaghan, Joanne. 2000. Reassessing the Feminist Theoretical Project in Law. Journal of Law and Society 27(3): 351-385.

Cowan, Sharon, and Chloë Kennedy, Jill Kennedy-McNeill, Ambreena Manji, Vanessa E. Munro, Sibongile Ndashe, Sharifah Sekalala, and Jhuma Sen. 2018. Feminist Judging: From Margin to Centre' Social and Legal Studies Blog. https://socialandlegalstudies.wordpress.com/2018/11/21/feministjudging-margin-centre/.

Cowan, Sharon, Chloë Kennedy, and Vanessa E. Munro (eds.). 2019. Scottish Feminist Judgments: (Re) Creating Law from the Outside in. Oxford: Hart Publishing.

Cowan, Sharon, and Chloë Kennedy and Vanessa E. Munro. 2020a. Seeing Things Differently: Art, Law and Justice in the Scottish Feminist Judgments Project (under review).

Cowan, Sharon, and Chloë Kennedy and Vanessa E. Munro. 2020b. The Scottish Feminist Judgments Project on Tour: (Re)Teaching and (Re)Learning Law. Canadian Legal Education Annual Review (forthcoming).

Crawford, Bridget, and Kathryn Stanchi, Linda L. Berger, Gabrielle J., Appleby, Susan Frelich, Appleton, Ross Astoria, Sharon Cowan, Rosalind Dixon, Troy Lavers, Andrea L McArdle, Elisabeth McDonald, Teri A McMurtry-Chubb, Vanessa E. Munro, and Pamela Wilkins. 2020. Teaching with Feminist Judgments: a Global Conversation. Law and Inequality: Journal of Theory and Practice 38(1).

Douglas, Heather, Francesca Bartlett, Trish Luker, and Rosemary Hunter (eds.). 2014. Australian Feminist Judgments: Righting and Rewriting Law. Oxford: Hart Publishing.

Enright, Maíréad, Julie McCandless, and Aoife O’Donoghue (eds.). 2017. Northern/Irish Feminist Judgments: Judges' Troubles and the Gendered Politics of Identity. Oxford: Hart Publishing.

Harrington, John, and Ambreena Manji. 2019. Africa Needs Many Lawyers Trained for the Need of Their Peoples: Struggles over Legal Education in Kwame Nkrumah's Ghana. American Journal of Legal History 59(2): 149-177.

Hewitt, Jeffrey. 2017. How Indigenous Art is Challenging Colonial Law. https://www.cigionline.org/artic les/how-indigenous-art-challenging-colonial-law.

Jack, Rand, and Dana Crowley Jack. 1989. Women Lawyers: Archetype and Alternatives. Fordham Law Review 57: 933-939.

Lorde, Audre. 1984. Sister Outsider: Essays and Speeches. Trumansburg, NY: The Crossing Press.

Majury, Diana. 2006. Introducing the Women's Court of Canada. Canadian Journal of Women and the Law 18(1): 1-7.

McDonald, Elisabeth, Rhonda Powell, Māmari Stephens, and Rosemary Hunter (eds.). 2017. Feminist Judgments of Aotearoa New Zealand: Te Rino: A Two-Stranded Rope. Oxford: Hart Publishing.

Mohanty, Chandra. 1988. Under Western Eyes: Feminist Scholarship and Colonial Discourses. Feminist Review 30(1): 61-88.

Munro, Vanessa E. 2007. Law and Politics at the Perimeter: Re-Evaluating Key Debates in Feminist Theory. Oxford: Hart Publishing.

Noddings, Nel. 1984. Caring: A Feminine Approach to Ethics and Moral Education. Berkeley: University of California Press.

Smith, Stephen W., John Coggon, Clark Hobson, Richard Huxtable, Sheelagh McGuinness, José Miola, and Mary Neal (eds.). 2017. Ethical Judgments: Rewriting Medical Law. Oxford: Hart Publishing.

Stalford, Helen, Kathryn Hollingsworth, and Stephen Gilmore (eds.). 2017. Rewriting Children's Rights Judgments: From Academic Vision to New Practice. Oxford: Hart Publishing.

Whitman, Christina. 1988. Law and Sex. Michigan Law Review 86: 1388-1403.

Publisher's Note Springer Nature remains neutral with regard to jurisdictional claims in published maps and institutional affiliations. 